\title{
Translation Challenges of Arabic Built-in-Language Repetition into English
}

\author{
Haitham (Mohd Khair) Ahmad ALYousef \\ Translation for professional department, School of Languages, Literacies and \\ Translation, Universiti Sains Malaysia \\ Penang, Malaysia \\ Tengku Sepora Tengku Mahadi \\ Translation for professional department, School of Languages, Literacies and \\ Translation, Universiti Sains Malaysia \\ Penang, Malaysia
}

\begin{abstract}
The present paper investigates Arabic built-in-language repetition that the researchers select from speeches delivered by the late president of Egypt Jamal Abdul Nasser, and the frequency of this phenomenon. The sample consists of 16 examples taken from chosen speeches. To ensure maximum accuracy, the researcher enlists the help of a professional translator to translate the study's samples. The study aims at detecting and shedding some light on translation's problems that the translator face when translating political texts. The results of the study indicate that builtin-language repetition exists in the Arabic translated text, and the use of repetition, in general, is more frequent in Arabic. The results also suggest that the translator should be fully aware of the Arabic and English linguistic systems as well as its culture to be able to convey the proper meaning.
\end{abstract}

Keywords: built-in-language repetition, problems, political discourse

Cites as: ALYousef, H. A., \& Mahadi, T. S. T. (2019). Translation Challenges of Arabic Builtin-Language Repetition into English. Arab World English Journal for Translation \& Literary Studies, 3 (3) 140 -150. DOI: http://dx.doi.org/10.24093/awejtls/vol3no3.10 


\section{Introduction}

A translation is a matter of equivalence between the source language text (SLT) and the target language text (TLT). The translator has to seek optimal translation by trying to preserve both the form and function of the source text. In this respect, Catford (1965) defines translation as "the replacement of textual material in one language (SL) by equivalent textual material in another language (TL).” (p.20).

Every language features specific uses and structures that reflect the convictions, values, beliefs, and intentions of its producers. This study investigates and analyzes the linguistic phenomenon of repetition in speeches delivered by Jamal Abdul Nasser with particular reference to their translation into English.

The present research relies heavily on previous studies and in particular, Shunnaq's (1989) categorization of built-in-language repetition, which the speakers usually employed due to the lack of choices. Whereas Shunnaq's research is concerned with repetition in general, this study investigates 'built-in-language repetition' in Nasser's speeches.

The researchers explain and discuss repetition challenges in greater depth; so translators are aware of its importance in general, and specifically the significant role it plays in political discourse. This study aims at examining the phenomenon of built-in-language repetition by exploring its various functions and types in political speeches. It is a device which produces the desired effect on the recipients through persuasion and emphasis. The user needs to use it in the appropriate place to be effective; otherwise, it will be devoid of sense. This study investigates and discusses repetition in Nasser's speeches focusing on the goals behind this repetition whenever employed and the challenges it causes for translators.

The present study can be assistance to both translators and linguists by showing some challenges in translating repetition in Nasser's speeches. It also reveals the importance of being aware of this phenomenon while translating political speeches from Arabic into English.

\section{Political Discourse}

Lyons (1991) observes:

The notion of communication is used to express feelings, moods, and attitudes. Language is used to perform many communication functions, and the most essential function language is the communication of views and information, the value of the use of language is to convey messages embodied in the cultural form (p.32).

Al-Hammed (1999, p.34) defines political discourse as a form of reflecting the living situation at a certain period, time. The reflection is in the form of words, expressions, idioms, and the structure that indicates specific goals that the speaker hopes to fulfill within that particular time and place. For further illustration, consider this Quranic verse:

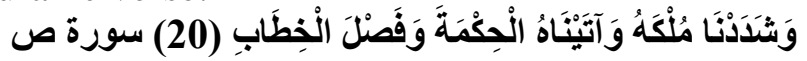


PT: We strengthened his kingdom, and gave him wisdom and sound judgment, in speech and decision. (Ali, 2008, p.1934)

In this example, the word (خطاب) is used to give the meaning of speech. The verse itself tells us that Allah gives prophet David the grace of persuasive and convincing speech. In our context, speech is written to promote an opinion or attitude of the general public toward an issue addressed. According to Larson (1998, p.6), the emotional reaction or response of SL or the dynamics of the text are untranslatable; since Muslim feelings towards the Quran are not the same as those of non-Muslims. Consequently, loss of meaning is inevitable on unavoidable at best. Nasser's speeches talked about economics, politics, religion, and culture.

Al-Hammed (1999, p.41) considers that socio-political discourse concerns addressing the society in its different conditions. This kind of speech usually discusses the social conditions of people from different classes and the difficulties they face in their daily life, in light of what the contemporary society witnesses the current developments.

Political discourse has its distinguishing jargon. Connolly (1993, p.2) points out the terms of political discourse refer to the vocabulary employed in political thought and the ploys adopted by politicians so that their words convey a unique and particular connotation.

Shunnaq (2000) indicates that a researcher should take into consideration the semantic phenomena in political discourse, such as emotiveness, figures of speech, and collocations. He specifically mentions that because translators should pay strict attention to these phenomena in both the source and target texts when translating between Arabic and English.

Newmark (2008, p.146) believes that because we are living in an age of cultural diversity as well as linguistic and psychological transformation, the translation of Arabic political discourse has come to the fore.

\section{Review of related literature}

Shunnaq $(1989,1992,1993,1994$, and 2000) dwells on the phenomenon of repetition, its types, functions and its relevance to translation, discussing repetition in Arabic political discourse (concerning translation). He (1989) distinguishes three kinds of repetition: built-in-language, functional and unnecessary and a repetition which exists by use of "word-strings," a term used to refer to "two or more different lexical items strung together to constitute one group, roughly showing the same meaning" (1992, p.6). He (1994) deals with semantic redundancy in both Arabic

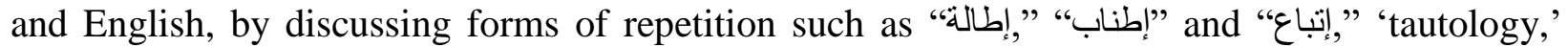
'pleonasm,' and 'binominals.' Hassan (2015) examines the translation of verb repetition from Arabic into English, where most translators avoid it. The repetition of a verb in Arabic indicates an assertion, a specific situation, or a reminder of a previous event. Hassan works on translation media and literary texts. He concludes that the deletion of repetition of the Arabic verb is best in English. Fathi (2004) examines repetition as a method of emphasis or reinforcement to speech in both languages' Arabic and English. Repetition is used in different fields to pay the attention of

Arab World English Journal for Translation \& Literary Studies 
the listener or reader. The study shows this phenomenon through the differences and similarities between the structures in Arabic and English. AlAubaidi (2013) considers the rhetorical function of repetition of sentences. It concludes that different methods of repetition indicate to varying features as assertion and the effects which emphasis adds to the sentence. Persson (1974) uses emphatic repetition to refer to all kinds of repetition that reinforces a concept such as a kind of repetition with emphatic, emotive, assertive, or connotative force (e.g., forget all about it. It's a false alarm, a false alarm). Ghazala (2012) recommends that translators should follow the writer whenever he repeats, even when repetition has no function, which is a view that the present researcher finds it challenging to agree.

Johnston (1991) investigates repetition as an emphatic style in most cases in Arabic discourse and regards it as a persuasive device. She discusses two kinds of repetition at the morphological level as follows: (a) repetition of patterns and (b) repetition of roots as in the cognate accusative. She concludes that repetition in English is a deviation from the norm, while in Arabic, it is not ornamental because it affects the structure of Arabic discourse.

\section{The Study}

This paper is a qualitative descriptive study examines the translation of Arabic built-inlanguage repetition as a stylistic device employed in the Arabic language system. The study consists of 16 examples taken randomly from selected speeches delivered by Nasser. A professional translator of political discourse translates these examples. The researchers classify them into a main category and two other subcategories. A main group is: built-in-language repetition, which has two different subcategories: (a) phonological level and (b) morphological level. The first subcategory includes the continual repetition of sounds and syllables. The second provides repetition created by case, number, and gender, which divides into six subcategories. A comparison between Arabic and English texts are made to analyze the collected to shed light on the problems that face the translator. Several Arabic built-in-language repetition examples are collected, and they comprise the corpora for the classifications of built-in-language repetition. The illustrative examples of each category are chosen purposefully from the speeches and discussed. Finally, the study suggests the reasons for the erroneous of translation in the discussion, and then the researchers propose suggested translations of the source language.

\section{Findings and Discussions}

The findings of the present study relate to Arabic built-in-language repetition and its categories and the problems that face the translator of the examples. The discussion focuses on the erroneous of translation where the translators have failed to render Arabic built-in-language repetition clauses to quite adequately in English; thus, the researcher proposes suggested translations.

\section{Built-in-language Repetition}

Repetition is a double-edged device; while it is a rhetorical device to create effectiveness, textual cohesion, and clarity, it can simultaneously produce redundancy. Repetition is also a vital process which may involve any unit of a text, such as morphemes, words, phrases, and even 
sentences (Nida, 1990, p.150). The speakers often use it more in spoken than in written discourse. This type of repetition is embedded in the language system, occurs in ordinary speech, and can be observed at different levels.

\subsection{Phonological level}

Newmark (2009, p.58) notes that translators should consider sound-effect, even at the level beyond the sentence, not only in poetry but also in jingles. The continual repetition of sounds and syllables such as -ing and -ed words and interjections has a powerful effect. In the following two examples, the repetition of the same sounds and morphemes appear clearly. Cruse (1991) defines homophone the repetition of the similar case ending in adjacent words or words in a parallel position.

: كل فرد منا مسؤول، ومسؤوليته تتساوى مع مسؤولية كل فرد من الحكومة من اجل بناء المجتمع الذي نريده. (1) مثال

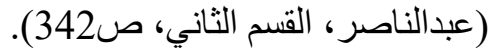

PT: Everyone of us is responsible, and; his responsibility is equal to that of every member of the government for the sake of building the society we want.

ST: Everyone of us is responsible; his responsibility is equal to the responsibility of each member of the government for the sake of building the society we want.

The researcher states that professional translation (PT) initially ignores "the responsibility," although it is essential in clarifying and emphasizing the full meaning of the sentence. The repetition is of the same sound /s/ in the four words: مسؤول، مسؤولية، تتساوى، مسؤولية in the repetition of the letter (w).

The repetition of the same morphemes (تم) appears at the end of the words in the following example:

مثال(2): انكم تتكرتح لأمتكم وتنكرنح لتاريخكموتنكرنم لقوتكم وتنكرنح لمجدكم. (عبدالناصر، الجزء الثالث_القسم الاول، ص1958). (1958)

PT: You ignored your nation, your history, your power, and your glory.

ST: You denied your nation, history, power, and glory.

In the above example, the sounds of the last pronoun in Arabic (تم) in the verbs give the rhythm of the speech. Neither PT nor ST involves the same repetition of those two morphemes in the English rendering. This example is sufficient to convince the reader that the Arabic version is more emotive and has a stronger impact than the English version due to the effect of the repetition of the same sound. 


\subsection{Morphological Level}

Morphology is a grammar branch that considers the forms, the structure, and the classes of words. Koch (1981) stresses the importance of the morphological system in Arabic as follows: The morphological system of Arabic is both linguistically and culturally the keystone of the language. The system is highly productive and easily accessible to the speakers of the language. Arabic speakers are very much aware of the system and use it in planning and in creating aphorism. A foreign learner of Arabic finds one of his first tasks to be learning lists of morphological patterns, since Arabic dictionaries are arranged alphabetically by roots rather than by word-initial letter. (p.90)

The present study shows that case, number, gender, definiteness and indefiniteness, and the nisba suffix in Arabic are morphological features of built-in-language repetition and have the function of conveying meanings like Shunnaq's previous studies.

\subsubsection{Repetition created by Case, Number, and Gender}

\subsubsection{Masculine Singular}

مثال (3): انني أشعر بالأمل . . . وذلك لأنني عشت مع النضال العربي منذ سنة 1952. (نورة عبدالناصر، ص1970) PT: I am hopeful . . . Because I have been living with the Arab struggle since 1952.

The adjective (العربي) agrees in gender (masculine) and number (singular) with the noun (النضال) which it modifies. In this case, the inanimate (النضال) does not change, as it would if it were animate (الرجل العربي).

مثال (4): اليوم اتحد الثعب العربي في سوريا. عبدالناصر (الجزء الثالث_القسم الأول،صل1958)

PT: Today, the Syrian Arab nation has unified.

ST: Today, the Arab people in Syria have unified.

Firstly, the researcher would like to correct the translation because it is unsuitable. The speaker did not mean the nation, but he said the people in Syria. Anyway, we can see there is no difference between this example and the previous one, both showing agreement of gender (masculine) and number (singular).

\subsubsection{Feminine Singular}

مثال (5): ولكننا لا نريد ديمقر اطيةز ائفة. عبدالناصر (ثورة عبدالناصر ، ص1952)

PT: But we do not want a pseudo democracy.

Here, the adjective (زائفة) agrees in gender (feminine) and number (singular) with the noun democracy (feminine, singular). It also appears in the following example:

مثال (6): الحياة القو مية الصحيحة هي حياة ديمقر اطية صحيحة. عبدالناصر (ثورة عبدالناصر ، ص1955)

PT: True national life is a truly democratic one.

Arab World English Journal for Translation \& Literary Studies

ISSN: 2550-1542 | www.awej-tls.org 
This example shows how the two adjectives (صحيحة) (ديمقر اطية) agree in gender (feminine) and number (singular) with the noun (حياة).

\subsubsection{Feminine Dual}

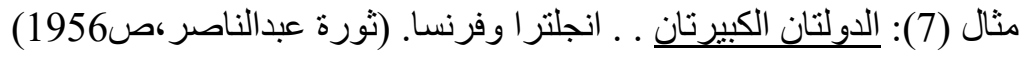

PT: The two great powers ... England and France.

ST: The two great states ... England and France.

The choice od diction of the word 'state' is more proper than 'powers.' As a result of a gender-number agreement, the dual morpheme -aan is twice repeated. The following example also shows the same agreement in gender and number, but with a different repeated morpheme -ain, i.e. the accusative form, it is unknown in English.

مثال (8): يجب أن يكون الحكم والثعب قوتين متعادلتين. (تورة عبدالناصر ، ص1952)

PT: Government and people should be two balanced powers.

It is meant to show a unique Arabic language system as different from that of the English language.

\subsubsection{Masculine Dual}

مثال (9): البلدان اللذان لم يعترفا بدولتكم هما: انجلتر اوفرنسا. (ثورة عبدالناصر ، ص1958)

PT: The two countries which haven't recognized your country are England and France.

The number and gender (masculine and dual) in the relative pronoun (اللذان) agrees the noun (the two countries) which is both masculine and dual. Besides, the morpheme -aan is repeated as a result of the number-gender agreement.

مثال (9): يجب أن نفرق بين شيئين أساسيين. (تورة عبدالناصر ، 1964)

PT: We must distinguish between two basic things.

The number-gender agreement also appears in the following example, but in the morpheme -ain. The translation in TL does not have the same morpheme.

مثال (10): وردا عليه قائلين. (ثورة عبدالناصر، 1964)

PT: They answered him, saying:

However, their English renditions do not look the same. For instance, the translator translates the dual in Arabic as plural in English. The translator should add an expression such as "both" or the "two of" to make his translation more exact.

\subsubsection{Feminine Plural}

مثال (11): و غدا نرى عشرات الصناعات. (ثورة عبدالناصر،1955)

PT: Tomorrow, we will see dozens of industries.

Arab World English Journal for Translation \& Literary Studies 
The repetition of the plural feminine morpheme -aat which is a suffix to the noun (الصناعات), and its adjective (عشرات) agree in number and gender, whereas the English version does not present these same characteristics. Therefore, the translator should be aware of the linguistic differences between two languages which influence the meaning equivalence.

\subsubsection{Masculine Plural}

مثال (12): سنسير يدا واحدة متعاونين منضامنين. (ثورة عبدالناصر ، 1954)

PT: We will move hand-in-hand, cooperatively, and in solidarity.

In this example, the number-gender agreement creates the repetition of the two plural morphemes -een suffixed to nouns in Arabic. The repetition of sounds in this example adds to the meaning, whereas it's English correspondence does not carry the same.

\subsubsection{Repetition forced by 'definiteness and indefiniteness.'}

Beeston (1990, p.24) discusses definiteness in Arabic and contrasts it with that in English. He points out that the Arabic definite article /al-/ has two quite distinct functions as follows: 'the particularizing function' and 'the generalizing function.' Only the context determines which is appropriate in the above two cases. While in English, usage fluctuates between zero article 'a,' and 'the.' The article /al-/* is used more prolifically in Arabic than the definite article 'the' in English. Consider the following example to explain this point:

مثال (13): الحرية الاجتماعية هي المدخل الِوحيد والِصحيح للِحرية السياسية. (ثورة عبدالناصر،1968) PT: Social freedom is the only appropriate entry to political freedom.

In Arabic, the definite article /al-/ is repeated seven times, whereas in English, the definite article is only used once. The above example shows how /al-/ in Arabic has prefixed adjectives and how a series of English nouns may be defined by one 'the.' The repetition of the morpheme /al-/ is also shown in the following example.

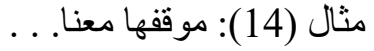

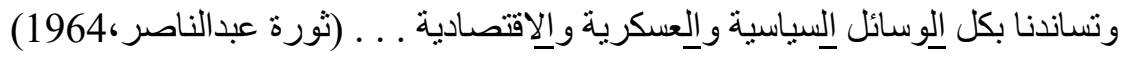

PT: It stands by us . . .

It supports us politically, militarily, and economically.

The morpheme /al-/ appears four times as a prefix, whereas, in English, the definite article is not used; despite this, the translator faithfully conveys the meaning of the Arabic sentence in English. Therefore, the use of the definite article is more prevalent in Arabic than in English.

\subsubsection{Repetition created by nisba suffix}

The present study uses morphemes (-iyya and $-i$ ) at the end of nouns to illustrate a morphological repetition. 
مثال (15): نريد كثفا لحساب الأرباح و الخسائر

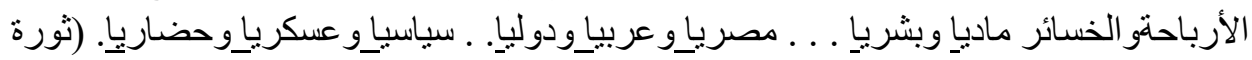

عبدالناصر ، 1961)

PT: We want a disclosure of gains and loses.

Financial and human gains and loses ... in Egypt, in the Arab world and international . . . political, martial and cultural levels.

The repetition of the nisba suffix (-i) in this example shows agreement between the word and the adjectives (كثف حساب) (ماديا وبشريا ومصريا و عربياودوليا وسياسيا و عسكريا وحضاريا) following it in number and gender. This repetition appears in eight words in Arabic, but it does not appear at all in English. It is axiomatic that there are differences between Arabic and English. The researcher points out these differences to enlighten translator about them. The following example also shows similar repetition but with a different nisba suffix (-iyya).

مثال (16): إننا لا نبغي فقط نهضة عمر انية أو صناعية أو عسكرية، ولكننا نبغي نهضة بشرية. (الجزء الأول،1953)

PT: We are not only after development in the construction, industry, or military fields; rather, we are after human development.

The repetition of the nisba suffix (-iyya) in four words shows agreement in number and gender, whereas there is nothing similar in English; anyone translating from Arabic into English should be aware of this difference.

\section{Conclusion}

This study concludes that built-in-language repetition phenomenon exists in Arabic more than in English. Any repeated word, expression, or idea in source language text should be dealt with and rendered carefully into the target language as it might serve a specific function. The translator of this kind of repetition should be fully aware of linguistic differences between the two languages which make the translation challenges.

\section{Acknowledgments:}

I wish to express my profound appreciation and love to my spiritual father and MA supervisor late Prof. Dr. Abdullah Shunnaq for his encouragement, support and assistance. (24/10/2017)

\section{About the Authors:}

Haitham ALYousef is a Ph.D. student in School of Languages, Literacies and Translation at Universiti Sains Malaysia. He is interested in teaching linguistic and translation courses. His research interests in interpreting, intercultural communication, language, and culture. More specifically, his work examines the linguistic aspects of translating humor. ORCID ID: https://orcid.org/0000-0002-7495-3563 
Professor Dr. Tengku Sepora Tengku Mahadi is a teaching staff at MA Translation for Professional Department in School of Languages, Literacies, and Translation. Universiti Sains Malaysia. She was the former dean for the school. Her research interests are in linguistics and translation fields. She has many types of researches in the fields. ORCID ID:

http://orcid.org/0000-0003-3302-0078

\section{References}

AL-Hammed, M. (1999). Political Discourse Analysis: An Arabic-English Contrastive Case Study (Unpublished master's thesis). Yarmouk University: Irbid, Jordan.

ALAubaidi, N. H. (2013). A Rhetorical Study of Emphasis in English with reference to Arabic. ADAB AL-FARAHIDI, 15, 60-78.

Ali, A. Y. (2008). The Qu'rān = Al-Qu'rān. Beltsville, MD: Foundations Library.

Beeston, A. F. (1990). Written Arabic: An approach to the basic structures. Cambridge: Cambridge University Press.

Catford, J. C. (1965). A Linguistic Theory of Translation. London: Oxford University Press.

Connolly, W. E. (1993). The terms of political discourse. Oxford: Blackwell.

Cruse, D. A. (1991). Lexical semantics. Cambridge: Cambridge University Press.

Fathi, Y. H. (2004). Reinforcement by repetition in English and Arabic. ADAB AL-RAFIDAYN, 38, 23-46. Retrieved from http://search.mandumah.com/Record/660334.

Ghazala, H. S. (2012). Translation as problems and solutions a textbook for university students and trainee translators. Jeddah: Konooz Al-Marefa.

Hassan, A. (2015). Translating Arabic Verb Repetition into English. Arab World English Journal, 6(2), 144-153. doi:10.24093/awej/vol6no2.11

Johnstone, B. (1991). Repetition in Arabic discourse. Amsterdam: J. Benjamins Pub.

Koch, B. J. (1981). Repetition in Discourse: Cohesion and Presentation in Arabic Argumentation Prose (Unpublished doctoral dissertation). University of Michigan.

Larson, M. L. (1998). Meaning-based translation: A guide to cross-language equivalence. Lanham: University Press of America.

Lyons, J. (1991). Introduction to theoretical linguistics. Cambridge: Cambridge University Press.

Newmark, P. (2008). About translation. Vancouver: Crane Library at the University of British Columbia.

Newmark, P. (2009). A textbook of translation. London: Prentice Hall.

Nida, E. A. (1990). The role of rhetoric in verbal communication. Babel, 36(3), 143-154. doi:10.1016/0271-5309(90)90022-4

Persson, G. (1974). Repetition in English: Part 1, sequential repetition. Uppsala: Universitatis Upsaliensis.

Shunnaq, A. T. (1989). Repetition in Arabic With Special Reference to Political Discource (Unpublished doctoral dissertation). The Victoria University of Manchester.

Shunnaq, A. (1992). Functional Repetition in Arabic realized through the use of word-string with reference to Arabic-English Translation of Political Discourse. Translation, 1(2), 5-31. 
Shunnaq, A. (1993). Patterns of Repetition in Arabic forced by Morphology with reference to Arabic-English Translation. Papers in Studies \& Contrastive Linguistics, 28, 89-99.

Shunnaq, A. (1994). Semantic Redundancy and Translation from Arabic into English. Turjuman, 3, 103-120.

Shunnaq, A. (2000). Arabic-English translation of political speeches. Perspectives, 8(3), 207-228. doi:10.1080/0907676x.2000.9961389

$$
\text { القرآن الكريم. العربية }
$$

$$
\begin{aligned}
& \text { المجمو عة الكاملة لخطب وأحاديث وتصريحات جمال عبدالناصر ، بيروت ـ مركز در اسات الوحدة العربية، الجزء الأول }
\end{aligned}
$$

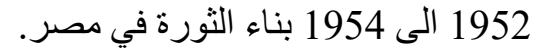

$$
\begin{aligned}
& \text { المجمو عة الكاملة لخطب و أحاديث وتصن وتصريحات جمال عبدالناصر ، بيروت ـ مركز در اسات الوحدة العربية، الجزء الثنالث ـ } \\
& \text { القسم الأول } 1958 \text { الى } 1959 \text { سنوات التهو الوحدة. } \\
& \text { مجمو عة خطب وتصريحات وبيانات الرئيس جمال عبدالناصر، بيروت ـ القاهرة - وزارة الارشاد القومي، القسم الثالث، } \\
& \text { فبر اير } 1958 \text { الى يناير } 1960 .
\end{aligned}
$$

